АНАЛИЗ РОЛИ ТАМОЖЕННЫХ ОРГАНОВ В ОСУЩЕСТВЛЕНИИ ВАЛЮТНОГО КОНТРОЛЯ Татьяна Олеговна АЛЕКСЕЕВА

студентка четвертого курса специальности таможенное дело,

Тверской государственный университет, Тверь, Российская Федерация

tanya101dm@yandex.ru

\section{История статьи:}

Получена 15.05.2017

Получена в доработанном

виде 01.06.2017

Одобрена 23.06.2017

Доступна онлайн 27.07.2017

УДК 338.23

JEL: F13

\section{Аннотация}

Предмет. Характер и содержание функций системы таможенных органов при осуществлении ими валютного контроля.

Цели. Раскрытие основных проблем и выявление приоритетных направлений развития валютного контроля Российской Федерации.

Методология. Методологическую основу исследования составили: системный метод научного познания, общетеоретические методы исследования (метод анализа, синтеза, сравнения, описания) и частнонаучные методы: формально-логический и сравнительно-правовой метод.

Результаты. Исследованы основные этапы проведения таможенными органами валютного контроля. Рассмотрена деятельность таможенных органов при передаче им функций органа валютного контроля. Раскрыта сущность главного документа валютного контроля - паспорта сделки. Выявлены основные проблемы и пути их решения при проведении валютного контроля таможенными органами.

Выводы. Таможенные органы как органы валютного контроля играют существенную роль в его осуществлении. Организационная структура таможенных органов дает возможность четко распределить деятельность на каждом ее уровне, тем самым обеспечивая в полной мере выполнение всех определенных валютным законодательством функций. При осуществлении таможенными органами валютного контроля возникают проблемы недостоверного заявления сведений декларантами в транспортных (перевозочных) и коммерческих документах, что в свою очередь влечет нарушение как валютного, так и таможенного законодательства. В настоящее время наиболее крупные нарушения валютного законодательства выявляются у юридических лиц, фактически прекративших свою деятельность на момент проведения проверочных мероприятий фирм-однодневок, что затрудняет процесс взыскания административных штрафов по данным Ключевые слова: валютный нарушениям и приводит к росту дебиторской задолженности перед федеральным контроль, таможенные органы, паспорт сделки, отток капитала, фирмыоднодневки бюджетом. По выявлению нарушений участниками ВЭД требований валютного законодательства необходимым является проведение модернизации и разработки новых программных средств, обеспечивающих ведение базы данных валютного контроля и обработку информации.

(C) Издательский дом ФИНАНСЫ и КРЕДИТ, 2017

Для цитирования: Алексеева Т.О. Анализ роли таможенных органов в осуществлении валютного контроля // Финансы и кредит. - 2017. - Т. 23, № 28. - С. 1678 - 1689.

https://doi.org/10.24891/fc.23.28.1678

$\begin{array}{llrlll}\text { Валютная политика является } & \text { составной } & \text { механизм валютного регулирования в } \\ \text { частью внешнеэкономической } & \text { политики } & \text { Российской } \text { Федерации представляется } \\ \text { государства, которая представляет собой } & \text { неотьемлемым условием для проведения } \\ \text { совокупность экономических, правовых } & \text { целостной валютной политики. Валютное } \\ \text { и организационных мероприятий, } & \text { регулирование можно определить, как правовое } \\ \text { осуществляемых государством в сфере } & \text { регламентирование порядка совершения } \\ \text { международных } \text { валютных } \text { отношений, } & \text { валютных операций. Основополагающим и } \\ \text { главной целью которой является поддержание } & \text { неотьемлемым элементом механизма } \\ \text { устойчивого равновесия в системе валютных } & \text { валютного регулирования является валютный } \\ \text { отношений. Поэтому результативно работающий } & \text { контроль, который можно рассматривать }\end{array}$


как вид государственного осуществляемый в целях государственной политики [1].

Под системой валютного регулирования и валютного контроля понимается система возникающих отношений между хозяйствующими субъектами в процессе совершения ими валютных операций и контролирующими субъектами (органами и агентами валютного контроля), при осуществлении ими валютно-контрольной деятельности ${ }^{1}$.

Более широкими полномочиями в сфере валютного контроля обладают органы валютного контроля. В отличие от агентов валютного контроля они вправе: издавать акты по вопросам, отнесенным к их компетенции; запрашивать и получать документы о проведении валютных операций, открытии и ведении счетов; выдавать предписания об устранении выявленных нарушений, а также применять меры ответственности [2].

Одна из главнейших задач валютного регулирования и валютного контроля - это противодействие утечке капитала за границу, которая может произойти из-за невозврата валютной выручки в Россию: заключение фиктивных контрактов, использование пробелов в валютном законодательстве, создание фирм-однодневок и дочерних компаний, зарегистрированных в офшорной зоне, неисполнение встречных обязательств по бартерным сделкам и другие нелегальные способы, принявшие форму бегства капитала $[3,4]$.

Совершенно очевидно, что его темпы будут расти и дальше при сохранении сегодняшней неопределенности в экономике, политической обстановке, а также нестабильности на мировых рынках, поэтому на подобном фоне нашей стране вряд ли удастся удержать капитал [5]. Указанные обстоятельства, последствиями которых является непоправимый

\footnotetext{
${ }^{1}$ Самохин Р.B. Особенности осуществления таможенными органами РФ валютного контроля в условиях Таможенного союза // Экономика, право и социум: современные модели развития общества. Материалы международной научнопрактической конференции / под ред. В.В. Пономарева, Т.А. Куткович. Ставрополь: Логос, 2014. С. 158-165.
}

экономический ущерб Российской Федерации, а также в целом национальной безопасности страны, требуют разрешения ситуации путем пересмотра законодательства о валютном регулировании и валютном контроле [6].

Для того чтобы приостановить сделки, имеющие признаки легализации незаконно полученных доходов, необходимо совмещать принципы предварительного и последующего валютного контроля с информированием соответствующих компетентных органов [7].

При неэффективном применении валютного контроля наша страна утрачивает значительную часть своего финансового потенциала. Так, например, свыше 1,3 трлн долл. США выведены из Российской Федерации на 2016 г. и хранятся в офшорах по всему миру ${ }^{2}$, становясь источником для развития экономик других государств, при этом ощущается недостаток в финансовых pecypcax для устойчивого развития национальной экономики [8].

Укреплению экономической безопасности нашей страны в силу специфики своих функций по противодействию негативным факторам во многом способствует деятельность таможенных органов при осуществлении валютного контроля, основные функции которой закреплены в ст. 12 Федерального закона от 27.11.2010 № 311-Ф3 «О таможенном регулировании в Российской Федерации». К ним относятся, во-первых, осуществление контроля за валютными операциями, связанными с перемещением товаров через таможенную границу ЕАЭС, с ввозом товаров в РФ и их вывозом из РФ; во-вторых, обеспечение мер по противодействию легализации доходов, полученных преступным путем, и финансированию терроризма, при осуществлении контроля за перемещением через таможенную границу ЕАЭС денежных средств и денежных инструментов.

Обладая информацией о фактах и сроках ввоза и вывоза товаров, характере и условиях внешнеэкономической операции, количестве,

\footnotetext{
${ }^{2}$ Offshore finance: more than $\$ 12 \mathrm{tn}$ siphoned out of emerging countries. URL: https://www.theguardian.com/business/2016/may/ 08/offshore-finance-emergingcountries- russia-david-cameronsummit
} 
качестве и цене товаров, таможенные органы осуществляют валютный контроль в рамках таможенного контроля при перемещении материальных и нематериальных объектов через таможенную границу [9].

В связи с изданием Указа Президента РФ от 02.02.2016 № $41 \ll \mathrm{O}$ некоторых вопросах государственного контроля и надзора в финансово-бюджетной сфере» Федеральная служба финансово-бюджетного надзора (Росфиннадзор) была упразднена. Функции данной структуры распределены между Федеральной таможенной службой (ФТС) и Федеральной налоговой службой (ФНС). Функции валютного контроля, связанные с перемещением товаров через таможенную границу ЕАЭС, их ввозом в РФ и вывозом из РФ, осуществляют таможенные органы. Соответственно, налоговые органы осуществляют валютный контроль за соблюдением резидентами требований о репатриации валютной выручки, оформления паспорта сделки, предоставления подтверждающих документов. Таким образом, в настоящее время за таможенными и налоговыми органами официально закрепился статус органов валютного контроля, что существенно расширило полномочия в данной сфере. Итак, таможенные органы теперь наделены полномочиями составлять протоколы об административном правонарушении, рассматривать соответствующие дела и выносить постановления при нарушении валютного законодательства.

Действующее нормативно-правовое регулирование валютного контроля включает Федеральный закон от 10.12.2003 № 173-Ф3 «О валютном регулировании и валютном контроле» (далее - Закон № 173-Ф3) и Инструкцию Банка России от 04.06.2012 № 138-И «О порядке представления резидентами и нерезидентами уполномоченным банкам документов и информации, связанных с проведением валютных операций, порядке оформления паспортов сделок, а также порядке учета уполномоченными банками валютных операций и контроля за их проведением», которая устанавливает порядок и форму заполнения паспорта сделки.

Валютный контроль осуществляется на каждом уровне четырехзвенной системы таможенных органов Российской Федерации. На уровне центрального аппарата ФТС России осуществлением валютного контроля занимается Управление торговых ограничений, экспортного и валютного контроля. Оно обеспечивает формирование и совершенствование ведомственной составляющей нормативной базы валютного контроля, представляет интересы ФТС России в государственных и иных органах при рассмотрении вопросов валютного контроля, осуществляет общее методическое руководство и координацию деятельности таможенных органов, связанной с валютным контролем, контролирует выполнение нижестоящими таможенными органами своих функций, организует информационный обмен, в том числе межведомственный ${ }^{3}$.

В региональном таможенном управлении (РТУ) функции валютного контроля выполняются подразделением валютного контроля службы федеральных таможенных доходов $\mathrm{PTY}^{4}$, который: организовывает проверки соблюдения участниками внешнеэкономической деятельности валютного законодательства и анализирует результаты проведения проверок; взаимодействует с органами и агентами валютного контроля; обобщает и анализирует статистические данные о результатах валютного контроля и т.Д.

Значительный объем работы по осуществлению валютного контроля приходится на таможни. Отделы валютного контроля и отделы контроля таможенной стоимости обладают широким кругом полномочий: принимают решения по

\footnotetext{
${ }^{3}$ Дудко А.А. Роль таможенных органов в осуществлении валютного контроля // Актуальные проблемы российского права и законодательства. Сборник материалов

IX Всероссийской научно-практической конференции студентов, аспирантов, молодых ученых. Красноярск: Сибирский институт бизнеса, управления и психологии, 2016. C. 64-67.

${ }^{4}$ Приказ ФТС России от 18.10.2016 № 1986 «Об утверждении типовых положений о подразделениях валютного контроля таможенных органов».
} 
вопросам валютного контроля, возникающим в ходе совершения таможенных операций; осуществляют проверки соблюдения участниками ВЭД валютного законодательства; проводят учет, обобщение и анализ данных о перемещении через таможенную границу физическими и юридическими лицами валюты РФ, иностранной валюты, внутренних и внешних ценных бумаг, и т.д.

Таможенные посты занимают низший уровень организации таможенной системы Российской Федерации. Валютный контроль на данном уровне осуществляется в ходе выполнения таможенными органами своих основных функций при проведении таможенного контроля товаров и транспортных средств.

Рассмотрим основные этапы проведения валютного контроля таможенными органами (puc. 1).

Первый этап - оформление участником ВЭД в уполномоченном банке для осуществления валютных операций паспорта сделки.

Базовым документом валютного контроля является паспорт сделки. Этот документ свидетельствует о прохождении валютной операции между резидентом и нерезидентом, а также необходим для целей учета и отчетности. Он оформляется на контракты, сумма которых равна или превышает 50000 долл. США в уполномоченном банке, где открыт валютный счет. Паспорт сделки не позднее двух рабочих дней после даты его оформления направляется банком резиденту участнику ВЭД для таможенного оформления. Следует отметить, что паспорт не представляется при помещении товаров под таможенные процедуры таможенного транзита, перемещения припасов, иные специальные таможенные процедуры (разд. 7, гл. 27 и 32 Таможенного кодекса Таможенного союза).

Второй этап - передача уполномоченным банком электронной копии паспорта сделки в ФТC.

Уполномоченный банк в день подписания оформленного (переоформленного) паспорта сделки формирует сообщение в электронном зашифрованном виде, содержащее информацию по данному паспорту и отправляет в $\Phi \mathrm{TC}^{5}$. Срок передачи оформленного паспорта не может превышать трех рабочих дней с даты его оформления в уполномоченном банке.

Третий этап - валютный контроль, осуществляемый до выпуска товаров.

Таможенные органы осуществляют валютный контроль с применением автоматизированных технологий, которые основываются на использовании электронных документов (паспортов сделок, деклараций на товары и ведомостей банковского контроля) [10]. Работа таможенных органов, в том числе при осуществлении валютного контроля, строится на основании системы управления рисками (далее-СУР).

По мнению Е.В. Зыбиной при оценке риска нарушения валютного законодательства с использованием сведений, находящихся в информационных ресурсах, Единой автоматизированной системе таможенных органов (например, паспорта сделки и ведомости банковского контроля, также другие сведения), необходимо проводить мониторинг и анализ по следующим критериям:

- предполагаемая сумма возможного нарушения валютного законодательства;

- возможность истечения сроков давности привлечения к административной ответственности;

- возможность привлечения к уголовной ответственности (определение сроков давности привлечения к уголовной ответственности по контрактам, предполагаемая сумма нарушения по которым свыше 6 млн руб.);

- информация о предыдущих нарушениях резидента;

\footnotetext{
${ }^{5}$ Положение «О порядке передачи уполномоченными банками и территориальными учреждениями Банка России в таможенные органы для выполнения ими функций агентов валютного контроля информации по паспортам сделок по внешнеторговым договорам (контрактам) в электронном виде» (утв. Банком России 29.12.2010 № 364-П).
} 
- информация о внешнеторговой деятельности резидента;

- направление движения денежных средств (факты перемещения денежных средств в банки, находящиеся в офшорных зонах) [11].

В целях валютного контроля на этапе оформления таможенные органы осуществляют проверку соответствия сведений, заявленных в декларации на товары (далее - ДТ) сведениям, содержащимся в документах, представленных в таможенный орган вместе с ДТ (внешнеторговый контракт, паспорт сделки, справка о валютных операциях $)^{6}$.

Основными графами в ДТ для целей валютного контроля являются следующие:

- графа 9 «Лицо, ответственное за финансовое урегулирование»;

- графа 22 «Валюта и общая стоимость по счету»;

- графа 24 «Характер сделки»;

- графа 44 «Дополнительная информация / Предоставленные документы» [12].

Как правило, декларантами некорректно заполняются графы 22 и 24.

Проверка достоверности сведений о паспорте сделки в ДТ осуществляется путем проверки его наличия по соответствующему номеру в базе данных валютного контроля, а затем происходит проверка его на соответствие представленному договору (по сведениям о лице - российском резиденте, заключившем договор, и номеру договора). Информация о зарегистрированных таможенными органами ДТ передается в Банк России и уполномоченные банки в электронном виде и вносится уполномоченным банком в ведомость банковского контроля по контракту в автоматизированном режиме не позднее трех рабочих дней со дня, следующего за датой

\footnotetext{
${ }^{6}$ Худякова Е.Н. Особенности валютного контроля при таможенном оформлении товаров // Наука и образование в социокультурном пространстве современного общества Сборник научных трудов по материалам Международной научно-практической конференции. Смоленск: Новаленсо, 2016. C. $97-99$.
}

выпуска (условного выпуска) таможенными органами товаров ${ }^{7}$.

Четвертый этап - валютный контроль, осуществляемый после выпуска товаров.

При выявлении уполномоченным банком факта нарушения валютного законодательства и непоступления валютной выручки в установленные контрактом сроки банк отправляет информацию о данном нарушении органу валютного контроля - Банку России на электронных носителях. Банк по истечении 180 календарных дней после завершения исполнения обязательств по контракту закрывает и архивирует паспорт сделки, даже при наличии нарушения валютного законодательства [13]. Банк России пересылает информацию о правонарушении, полученную от уполномоченного банка, органам валютного контроля - налоговым и таможенным.

В процессе проведения таможенной проверки отделы таможенного контроля после выпуска товаров (далее - ТК ПВТ) собирают информацию о предпринимаемых проверяемым субъектом действиях, направленных на сокрытие имеющих место правонарушений, связанных с нарушением валютного законодательства. В рамках ТК ПВТ таможенные органы осуществляют межведомственное взаимодействие в первую очередь с налоговыми, правоохранительными и финансовыми органами [14]. В данном взаимодействии осуществляется обмен и передача информации по конкретным объектам проверки или выявленным схемам нарушений валютного законодательства. Наиболее важным направлением взаимодействия, осуществляемым подразделениями ТК ПВТ, является сотрудничество с территориальными органами налоговой службы. Одно из главных направлений проверочных мероприятий, проводимых отделами ТК ПВТ во взаимодействии с налоговыми органами, обеспечение контроля за деятельностью

\footnotetext{
7 Постановление Правительства РФ от 28.12.2012 № 1459 «О порядке передачи таможенными органами Центральному банку Российской Федерации и уполномоченным банкам в электронном виде информации о зарегистрированных таможенными органами декларациях на товары».
} 
участников ВЭД, в отношении которых имеется информация об их участии в схемах уклонения от уплаты таможенных пошлин и налогов, от ответственности за нарушения таможенных правил, налогового и валютного законодательства РФ, механизмы которых, основываются на деятельности фирмоднодневок ${ }^{8}$. Негативные последствия от деятельности подобных организаций выражаются в потенциальной невозможности проведения в их отношении контрольных мероприятий, a также в невозможности последующего взыскания с таких фирм неуплаченных в доход государства обязательных платежей и причитающихся штрафных санкций [15]. Исходя из этого, противодействие деятельности участников ВЭД, имеющих признаки фирм-однодневок, целесообразно проводить прежде всего на этапе таможенного оформления перемещаемых ими товаров, однако выявление признаков отнесения организаций к данной категории лиц таможенными органами осуществимо только в рамках проведения контроля после выпуска товаров.

По результатам таможенной проверки в случаях, если выявляется административное правонарушение в области валютного законодательства, таможенные органы принимают решение о возбуждении дела об административном правонарушении в виде определения, а по окончании административного расследования таможенный орган выносит постановление о привлечении лица к административной ответственности (ст. 15.25 КоАП РФ). Обнаружив признаки преступления (ст. 193, 193.1 УК РФ), таможенные органы возбуждают уголовное дело и проводят неотложные следственные действия, а затем передают его в прокуратуру для дальнейшего его расследования и направления в суд. Деяния, предусмотренные данными статьями,

\footnotetext{
${ }^{8}$ Штоль T.Э. Совершенствование проведения и организации таможенной проверки в части борьбы с «фирмами-однодневками» // Электронный сборник материалов Международной конференции студентов, аспирантов и молодых ученых «Проспект Свободный-2016», посвященной году образования в Содружестве Независимых Государств. Красноярск: Сибирский федеральный университет, 2016. С. 30-33.
}

признаются совершенными в крупном размере, если сумма невозвращенных денежных средств превышает 9 млн руб., а в особо крупном размере -45 млн руб.

Необходимым является совершенствование взаимодействия информационных систем ФТС и ФНС в сфере валютного контроля. В настоящее время ФТС России принимает активное участие в рассмотрении и согласовании разработанных Минфином России проектов документов по созданию единого механизма таможенного и налогового администрирования, а также валютного контроля9. Наиболее эффективным выглядит обеспечение информационного обмена между системами ФТС и ФНС в режиме реального времени. В перспективе идеальной площадкой для такого обмена могла бы стать система межведомственного электронного взаимодействия (СМЭВ). Интеграция информационных систем ФТС и ФНС позволит получить полную картину внешнеэкономической деятельности юридических лиц, что позволит Минфину России пресечь возможность применения серых схем при уплате таможенных платежей и должно положительно сказаться на полноте собираемости налогов и сборов.

В настоящее время основными нарушениями валютного законодательства являются:

1) несоблюдение участниками ВЭД требований ст. 19 Закона № 173-Ф3 об обязанности резидента при осуществлении внешнеторговой деятельности обеспечить получение от нерезидентов на свои банковские счета в уполномоченных банках иностранной валюты или валюты РФ, причитающейся в соответствии с условиями контрактов. Так, например, Калининградская областная таможня в 2015 г. выявила факт завышения декларантом стоимости ввозимого товара, которая в ДТ составляла 52223 093,92 руб. за 6 шт. Однако по результатам таможенной экспертизы товара его рыночная стоимость была определена в размере 4124880 руб.

${ }^{9}$ ФТС России. Новости Федеральной Таможенной Службы, 2017. URL: http://www.customs.ru 
Таким образом, декларант заявил стоимость товара в 12,66 раз выше рыночной. Информация по данной декларации была направлена в Банк России для предотвращения перевода денежных средств в адрес контрагента ${ }^{10}$;

2) нарушение требования подп. 2, п. 2 ст. 24 Закона № 173-Ф3 об обязанности резидента при осуществлении валютных операций вести в учет и составлять отчетность по проводимым валютным операциям;

3) несоблюдение участниками ВЭД единых правил оформления резидентами в уполномоченных банках паспорта сделки при осуществлении валютных операций между резидентами и нерезидентами, установленных Инструкцией Банка России № 138-И.

Одной из основных проблем в сфере валютного контроля являются пробелы в валютном законодательстве. Существуют нормы, позволяющие участникам ВЭД находить не противоречащие закону схемы ухода от ответственности. Так, согласно ч. 1 ст. 19 Закона № 173-Ф3 сроки репатриации определяются условиями внешнеторговых контрактов, что не исключает возможности увеличения данных сроков путем заключения участниками ВЭД дополнительных соглашений к контрактам ${ }^{11}$.

В 2016 г. таможенными органами проведено 5,1 тыс. проверок соблюдения участниками ВЭД требований актов валютного законодательства Российской Федерации ${ }^{12}$. По фактам нарушения таможенные органы возбудили 170 уголовных дел по ст. 193 УК РФ «Уклонение от исполнения обязанностей по репатриации денежных средств в

\footnotetext{
${ }^{10}$ Таможенная служба Российской Федерации в 2016 г. URL: http://www.customs.ru

${ }^{11}$ Куликова Ю.А. Организация валютного контроля экспортно-импортных операций, осуществляемого таможенными органами // Современные проблемы теории и практики таможенного дела глазами молодых исследователей. Материалы Региональной научно-практической интернетконференции. Улан-Удэ: Восточно-Сибирский государственный университет технологий и управления, 2015. C. $107-111$.

12 ФТС России. Новости Федеральной Таможенной Службы, 2017. URL: http://www.customs.ru
}

иностранной валюте или валюте РФ», 142 дела по ст. 193.1 УК РФ «Совершение валютных операций по переводу денежных средств в иностранной валюте или валюте РФ на счета нерезидентов с использованием подложных документов» на сумму свыше 19 млрд руб. Около 6 тыс. дел об АП по ст. 15.25 КоАП РФ (нарушение валютного законодательства РФ и актов органов валютного регулирования) на сумму 165 млрд руб. (в 2015 г. проведено 4,5 тыс. проверок, возбуждено и передано на рассмотрение более 5,3 тыс. дел об АП по ст. 15.25 КоАП РФ на сумму 180,1 млрд руб.). Значительную часть дел об АП (49\%) составляют дела, возбужденные таможенными органами по нарушениям, ответственность за совершение которых предусмотрена ч. 4 и 5 ст. 15.25 КоАП $\mathrm{P} \Phi^{13}$.

Одним из важных элементов развития совершения таможенных операций и процедур валютного контроля является организация взаимодействия с участником ВЭД посредством электронного сервиса «Личный кабинет участника ВЭД», обеспечивающего информационное взаимодействие в электронном виде между ФТС и участниками ВЭД. В информационном сервисе «Валютный контроль» для участников ВЭД реализована возможность получения имеющейся в информационных ресурсах таможенных органов информации об оформленных паспортах сделки и о переданных уполномоченным банкам таможенными органами ДТ, что позволяет до подачи ДТ проверить наличие паспорта в информационных ресурсах таможенных органов и заявлять сведения о нем в ДТ.

Валютное законодательство на уровне ЕАЭС остается больше национальным. Различие в механизмах осуществления валютного контроля в странах - участницах ЕАЭС выражается в существенном отличии перечней и объемов документов уполномоченных органов, которые требуются при проведении валютного контроля [16]. Попытки к гармонизации успешно предпринимаются

\footnotetext{
13 Таможенная служба Российской Федерации в 2016 г. URL: http://www.customs.ru
} 
государствами. Так, например, договором о ЕАЭС обозначены цели и принципы согласованной валютной политики: поэтапное осуществление гармонизации и сближения подходов к формированию и проведению валютной политики; создание необходимых организационно-правовых условий на национальном и межгосударственном уровнях для развития интеграционных процессов в валютной сфере, координации и согласования валютной политики и т.д. ${ }^{14}$.

В качестве подведения итога можно сделать вывод о том, что для обеспечения экономической безопасности страны необходимо постоянно совершенствовать механизмы валютного контроля. Например, разработка электронных сервисов, функционирующих в режиме реального времени, разработка новых профилей риска в СУР для осуществления контроля за валютными операциями в соответствии с требованиями валютного законодательства.
Основные направления деятельности таможенных органов при осуществлении валютного контроля - это повышение результативности таможенного администрирования, а также улучшение эффективности выполнения валютноконтрольных и регулирующих функций.

В настоящее время алгоритм выявления фирмоднодневок строится на тщательном и всестороннем анализе всей имеющейся у таможенных органов информации как об отдельной поставке товара, так и о деятельности участника ВЭД в целом, при этом особое значение имеет информация, получаемая из налоговых органов. Таможенным и налоговым органам необходимо выработать совместные методические рекомендации по противодействию деятельности участников ВЭД, имеющих признаки фирм-однодневок. Перечисленные мероприятия повысят качество контроля над участниками ВЭД и приведут к снижению количества нарушений в сфере валютного законодательства.

\footnotetext{
14 Договор о Евразийском экономическом союзе (подписан в Астане 29.05.2014).
} 


\section{Рисунок 1}

Основные этапы проведения валютного контроля таможенными органами

\section{Figure 1}

The main stages of foreign exchange control by Customs authorities

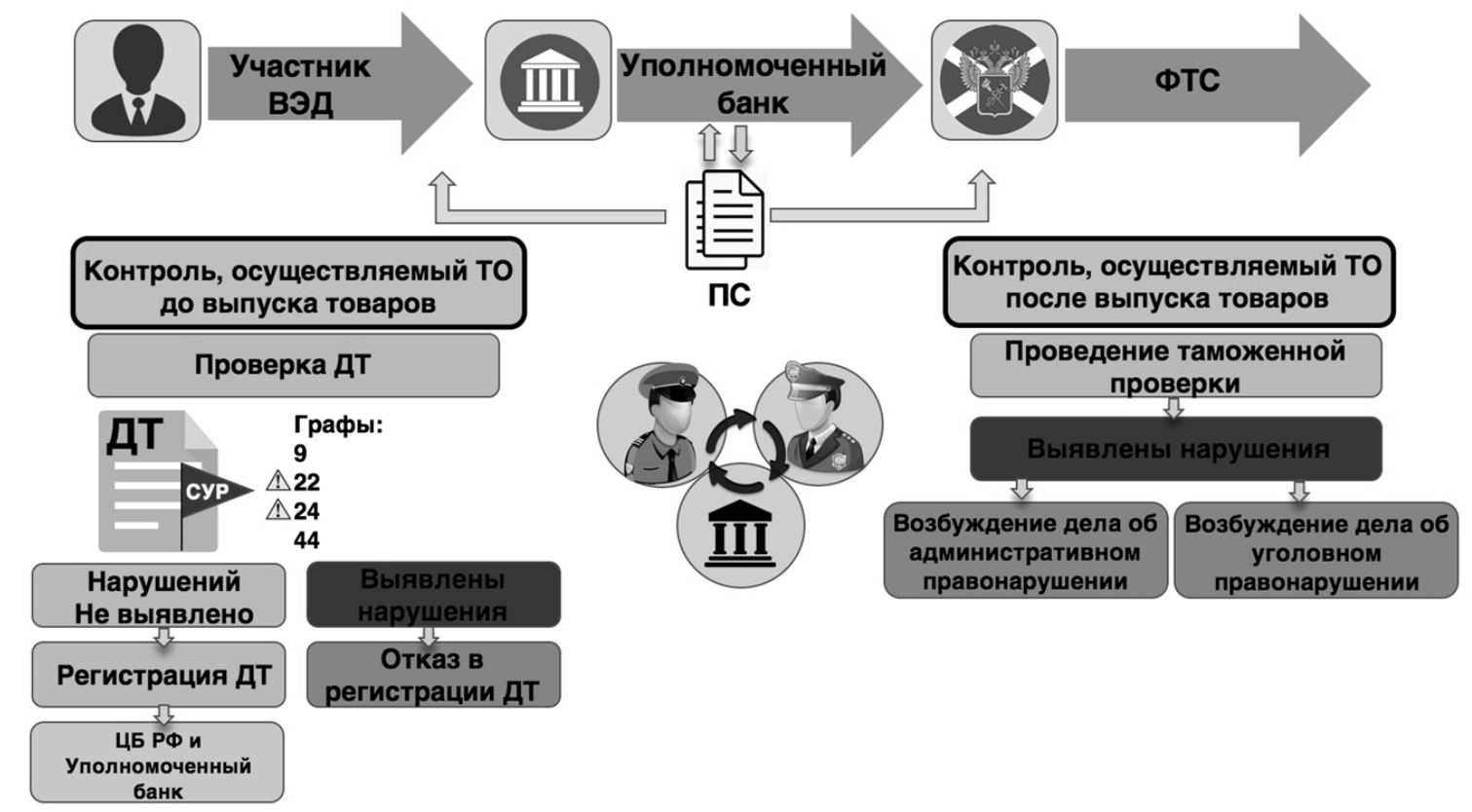

Источник: составлено автором

Source: Authoring

\section{Список литературы}

1. Aidarhanova K.N., Kabanbayeva G.B., Kuderin I.K. et al. Place of Currency Law in the System of Law. Life Science Journal, 2014, vol. 11, spec. iss. 4, pp. 257-260.

2. Курилов К.Ю., Колачева Н.В. Система валютного контроля в России // Карельский научный журнал. 2017. Т. 6. № 1. С. 53-56.

3. Селюков M.B., Худякова E.H. К вопросу о развитии валютного контроля в системе таможенных органов РФ (на примере Белгородской таможни) // Фундаментальные исследования. 2016. № 5-1. С. 194-197.

4. Хамаганова Л.Д. Роль валютного контроля региональной таможни при проведении экспортно-импортных операций в условиях нестабильности мировой экономики // Baikal Research Journal. 2011. № 1. C. 40.

5. Проблемы выживания и развития экономики России: коллективная монография / под ред. В.А. Петрищева. Тверь: Твер. гос. ун-т, 2016. 212 с. URL: http://eco.tversu.ru/Doc/nrabprep/mon_koll.pdf

6. Подосинников Е.Ю. Валютный контроль: понятие, сущность и роль в системе валютного регулирования // Актуальные проблемы социально-гуманитарного и научно-технического знания. 2016. № 3. C. 16-20. URL: http://xn--80aaa6bfh1d9b.xn--80aa3akelis.xn-clavg/assets/podosinnikov_valiutnyi_kontrol.pdf

7. Маркова О.М. Развитие системы валютного регулирования и валютного контроля России в условиях экономических санкций // Приоритетные направления развития науки и образования. 2015. № 2. С. 411-414. 
8. Немирова Г.И., Сокольникова О.Б. Валютный контроль как инструмент борьбы с нелегальным вывозом капитала из Российской Федерации // Российский экономический интернет-журнал. 2016. № 4. C. 1-15. URL: http://www.erej.ru/upload/iblock/e7c/e7c20391db79779f092d05ce7ccf6169.pdf

9. Модернизация механизмов развития экономики России / под ред. А.Н. Сухарева. Тверь: Твер. гос. ун-т, 2016. 116 с.

10. Медведенко O.B. Роль и статус таможенных органов Российской Федерации при осуществлении валютного контроля // Ученые записки Санкт-Петербургского им. В.Б. Бобкова филиала Российской таможенной академии. 2014. № 4. С. 58-64.

11. Зыбина E.B. Проблемы и перспективы валютного контроля, осуществляемого таможенными органами Российской Федерации в современных условиях // Транспортное дело России. 2015. № 3. С. 89-93.

12. Медведенко O.B. Роль таможенных органов в обеспечении экономической безопасности России при осуществлении валютного контроля // Таврический научный обозреватель. 2017. № 1. C. 47-53. URL: http://tavr.science/stat/2017/01/TNO-18.pdf

13. Блейхер O.B. Модернизация методов таможенного контроля после выпуска товаров 44-й товарной группы товарной номенклатуры внешнеэкономической деятельности // Общество: политика, экономика, право. 2016. № 4. С. 62-64.

14.Бондаренко Н.П. Таможенный контроль после выпуска товаров: современное состояние и перспективы развития // Наука и образование: хозяйство и экономика; предпринимательство; право и управление. 2016. № 9. С. 32-36.

15. Власов Д.Г. Методика организации и проведения совместной с налоговым органом выездной таможенной проверки импортных операций // Современные наукоемкие технологии. Региональное приложение. 2014. № 4. С. 14-23. URL: https://www.isuct.ru/epubl/snt/sites/ru.e-publ.snt/files/2014/04/snt_2014_n04.pdf

16. Матвеев M.M. Проблемы валютной интеграции в условиях Евразийского экономического союза // Экономика и менеджмент инновационных технологий. 2015. № 9. С. 13-17. URL: http://ekonomika.snauka.ru/2015/09/7916

\section{Информация о конфликте интересов}

Я, автор данной статьи, со всей ответственностью заявляю о частичном и полном отсутствии фактического или потенциального конфликта интересов с какой бы то ни было третьей стороной, который может возникнуть вследствие публикации данной статьи. Настоящее заявление относится к проведению научной работы, сбору и обработке данных, написанию и подготовке статьи, принятию решения о публикации рукописи. 


\title{
ANALYSIS OF THE ROLE OF CUSTOMS AUTHORITIES IN THE EXERCISE OF CURRENCY CONTROL
}

\section{Tat'yana O. ALEKSEEVA}

Tver State University, Tver, Russian Federation

tanya101dm@yandex.ru

\begin{abstract}
Article history:
Received 15 May 2017

Received in revised form

1 June 2017

Accepted 23 June 2017

Available online 27 July 2017

JEL classification: F13

Keywords: foreign exchange control, customs authorities, transaction certificate, capital outflow, short-lived company

Abstract

Importance The article discusses the nature and content of the functions of customs authorities in conducting the currency exchange control.

Objectives The paper aims to reveal the main problems and identify the priority directions of development of currency exchange control in the Russian Federation.

Methods For the study, I used a systems method of knowledge, general theoretical methods like the methods of analysis, synthesis, comparison, description, and specific scientific methods like the formal-logical and comparative legal methods.

Results I have analyzed the main stages of currency control of customs bodies, and I reveal the basic problems and their solutions in the performance of currency control. The paper shows the main point of the master currency control document that is a currency transaction report form.

Conclusions To identify violations of foreign trade operators, it is necessary to modernize and develop new software for maintaining a currency control database and information processing.
\end{abstract}

Please cite this article as: Alekseeva T.O. Analysis of the Role of Customs Authorities in the Exercise of Currency Control. Finance and Credit, 2017, vol. 23, iss. 28, pp. 1678-1689.

https://doi.org/10.24891/fc.23.28.1678

\section{References}

1. Aidarhanova K.N., Kabanbayeva G.B., Kuderin I.K. et al. Place of Currency Law in the System of Law. Life Science Journal, 2014, vol. 11, spec. iss. 4, pp. 257-260. doi: $10.7537 /$ marslsj1104s14.42

2. Kurilov K.Yu., Kolacheva N.V. [Foreign Exchange Control System in Russia]. Karel'skii nauchnyi zhurnal = Karelian Scientific Journal, 2017, vol. 6, iss. 1, pp. 53-56. (In Russ.)

3. Selyukov M.V., Khudyakova E.N. [To the question about the development of currency control in the system of customs bodies of the Russian Federation (for example, the Belgorod Customs)]. Fundamental'nye issledovaniya = Fundamental Research, 2016, vol. 5, no. 1, pp. 194-197. (In Russ.)

4. Khamaganova L.D. [Role of the regional customs currency control when carrying out exportimport transactions in the context of economic instability]. Baikal Research Journal, 2011, no. 1, p. 40. (In Russ.)

5. Petrishchev V.A. (ed.). Problemy vyzhivaniya i razvitiya ekonomiki Rossii: kollektivnaya monografiya [Issues of survival and development of the Russian economy: a collective monograph]. Tver, Tver State University Publ., 2015, 212 p. URL: http://eco.tversu.ru/Doc/nrabprep/mon_koll.pdf 
6. Podosinnikov E.Yu. [Currency control: definition, essence and the role in the system of currency regulation]. Aktual'nye problemy sotsial'no-gumanitarnogo i nauchno-tekhnicheskogo znaniya = Acute Problems of Social, Academic and Scientific Technical Knowledge, 2016, no. 3, pp. 16-20. URL: http://xn--80aaa6bfh1d9b.xn--80aa3akelis.xn-clavg/assets/podosinnikov_valiutnyi_kontrol.pdf (In Russ.)

7. Markova O.M. [Development of currency regulation system and currency control of Russia in the terms of economic sanctions]. Prioritetnye napravleniya razvitiya nauki $i$ obrazovaniya $=$ Priority Directions of Science and Education Development, 2015, no. 2, pp. 411-414. (In Russ.)

8. Nemirova G.I., Sokol'nikova O.B. [Currency control as a tool to combat with the illegal export of capital from Russia]. Rossiiskii ekonomicheskii internet-zhurnal, 2016, no. 4, pp. 1-15. (In Russ.) URL: http://www.e-rej.ru/upload/iblock/e7c/e7c20391db79779f092d05ce7ccf6169.pdf

9. Sukharev A.N. (ed.). Modernizatsiya mekhanizmov razvitiya ekonomiki Rossii: monografiya [Improving the mechanisms for Russia's economic development: a monograph]. Tver, TSU Publ., 2016, 116 p.

10. Medvedenko O.V. [Role and status of customs authorities of the Russian Federation in the exercise of foreign exchange control]. Uchenye zapiski Sankt-Peterburgskogo imeni V.B. Bobkova filiala Rossiiskoi tamozhennoi akademii = Scholarly Notes of Saint Petersburg after V.B. Bobkov Branch of the Russian Customs Academy, 2014, vol. 4, pp. 58-64. (In Russ.)

11. Zybina E.V. [Problems and prospects walutowa of control exercised by the customs authorities of the Russian Federation in modern conditions]. Transportnoe delo Rossii = Transport Business of Russia, 2015, vol. 3, pp. 89-93. (In Russ.)

12. Medvedenko O.V. [The role of customs in economic security provision of Russia]. Tavricheskii nauchnyi obozrevatel $=$ Taurida Observer, 2017, no. 1, pp. 47-53. URL: http://tavr.science/stat/2017/01/TNO-18.pdf (In Russ.)

13. Bleikher O.V. [Improvement of customs control after the release of goods of the 44 commodity section of the foreign economic activity commodity nomenclature]. Obshchestvo: politika, ekonomika, pravo = Society: Politics, Economics, Law, 2016, no. 4, pp. 62-64. (In Russ.)

14. Bondarenko N.P. [Customs control after release of goods as the major trend of Russian customs service activity]. Nauka i obrazovanie: khozyaistvo i ekonomika; predprinimatel'stvo; pravo $i$ upravlenie = Science and Education: Economy and Economics; Business; Law and Management, 2016, no. 9, pp. 32-36. (In Russ.)

15. Vlasov D.G. [The methodology of organization and carrying out of import operation exit customs examination joint with tax authority]. Sovremennye naukoemkie tekhnologii. Regional'noe prilozhenie = Modern High Technologies. Regional Application, 2014, no. 4, pp. 14-23. URL: https://www.isuct.ru/e-publ/snt/sites/ru.e-publ.snt/files/2014/04/snt_2014_n04.pdf (In Russ.)

16. Matveev M.M. [Problems of currency integration in the conditions of the Eurasian Economic Union]. Ekonomika $i$ menedzhment innovatsionnykh tekhnologii $=$ Economics and Innovations Management, 2015, no. 9, pp. 13-17. URL: http://ekonomika.snauka.ru/2015/09/7916 (In Russ.)

\section{Conflict-of-interest notification}

I, the author of this article, bindingly and explicitly declare of the partial and total lack of actual or potential conflict of interest with any other third party whatsoever, which may arise as a result of the publication of this article. This statement relates to the study, data collection and interpretation, writing and preparation of the article, and the decision to submit the manuscript for publication. 